\title{
Revisiting reproduction and population structure and dynamics of Procambarus clarkii eight years after its introduction into Lake Trasimeno (Central Italy)
}

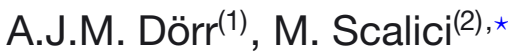 \\ Received November 27, 2012 \\ Revised April 8, 2013 \\ Accepted April 9, 2013
}

\section{ABSTRACT}

Key-words: red swamp crayfish,

Procambarus clarkii, reproduction, population structure and population dynamics, invasive species

\section{RÉSUMÉ}

Understanding population dynamics and regulation is fundamental for predicting establishment and spread of invasive alien species. In addition, the population biology of invasive alien species offers an opportunity to study basic ecological processes. In this context, we investigated reproductive and growth plasticity in the invasive crayfish Procambarus clarkii in Lake Trasimeno (central Italy). In total, 3153 crayfish were collected monthly from June 2007 to July 2009. The molt status was assessed by evaluating the exoskeleton hardness. To assess the reproductive cycle, the gonado-somatic and wet hepato-somatic indices were calculated for females. The reproductive status of males was appraised as well. We estimated growth and longevity using the von Bertalanffy growth function, and calculated the total, natural and fishing mortality indices. We then compared our present data with those obtained from the same population eight years before. Our results indicate some changes in population dynamics and in both molting and reproductive periods since the initial invasion of the shallow lake investigated. Long-term differences in the life history of the Trasimeno population may be the result of selective pressures different from those of the native range, but may also result from colonization events and human interference caused by professional fishing activities.

Réexamen de la reproduction, de la structure de population et de la dynamique de Procambarus clarkii huit ans après son introduction dans le lac Trasimène (Italie centrale)

\begin{abstract}
Mots-clés :
Comprendre la dynamique de population et sa régulation est essentielle pour préécrevisses rouges

de marais, Procambarus clarkii, reproduction, dynamique de population, voir l'établissement et la propagation des espèces exotiques envahissantes. En outre, la biologie des populations d'espèces exotiques envahissantes offre l'occasion d'étudier des processus écologiques de base. Dans ce contexte, nous avons étudié la plasticité de la reproduction et de la croissance de l'écrevisse Procambarus clarkii invasive dans le lac Trasimène (Italie centrale). Au total, 3153 écrevisses ont été recueillies chaque mois de juin 2007 à juillet 2009. L'état de la mue a été estimé en évaluant la dureté de l'exosquelette. Pour évaluer le cycle de reproduction, les rapports gonado-somatique et hépato-somatique (poids frais) ont été calculés pour les femelles. Le statut reproducteur des mâles a été évalué de
\end{abstract}

(1) Department of Cellular and Environmental Biology, University of Perugia, via Elce di Sotto, snc - 06123, Perugia, Italy

(2) Department of Science, University of «Roma Tre », v.le G. Marconi 446, 00146 Roma

* Corresponding author: massimiliano.scalici@uniroma3.it 
structure de population, espèces envahissantes même. Nous avons estimé la croissance et la longévité en utilisant la fonction de croissance de von Bertalanffy, et calculé les indices de mortalité totale, naturelle et par pêche. Nous avons ensuite comparé nos données actuelles à celles obtenues à partir de la même population huit ans auparavant. Nos résultats indiquent des changements dans la dynamique des populations et dans les deux périodes de mue et de reproduction depuis l'invasion initiale de ce lac peu profond. Les différences à long terme dans le cycle de vie de la population du Trasimène peuvent être le résultat de pressions sélectives différentes de celles de l'aire de répartition naturelle, mais peuvent aussi résulter d'événements de colonisation et de l'interférence humaine causée par les activités de pêche professionnelle.

\section{INTRODUCTION}

Preventing the introduction of invasive species appears to be the most environmentally acceptable approach to avoid negative economic impacts and ecosystem collapse (Gollasch and Leppäkoski, 1999). At early stages of invasion, the removal of the alien taxa may be effective with little knowledge of the introduced species' ecology (Simberloff, 2003), but once the opportunity for early eradication has been lost, biological details are useful to develop procedures for an effective management strategy (see Scalici et al., 2009b). Mechanisms of population dynamics and regulation have attracted interest from ecologists (e.g., Murray, 1979; Huffaker et al., 1984; Turchin, 1999; Krebs, 2002) since this issue is fundamental for predicting the invasiveness of alien taxa (Capinha et al., 2011) and for elaborating control strategies (Takimoto, 2009; Burlakova et al., 2010).

Alien taxa often show an explosive increase in abundance soon after establishment, reaching high levels of biomass and density. This initial explosion may drive researchers to erroneous conclusions regarding the alien population status, since colonizing new habitats may facilitate the expression of emergent population properties (Strayer et al., 2006; Strayer, 2010). These emerging features can gradually shift, after a certain period after introduction (Ezard et al., 2010), generating difficulties in predicting the spread and population dynamics of alien species in freshwater ecosystems.

To date, several aspects of the life history of alien crayfish have been collected (see SoutyGrosset et al., 2006; DAISIE, 2009), since they act as keystone species of littoral food webs (Nyström, 1999, 2002), dominating a variety of freshwater communities (Usio and Townsend, 2004), being among the longest-lived invertebrates in temperate areas (Scalici et al., 2008a,c), general polytrophic omnivorous consumers (Momot, 1995; Whitledge and Rabeni, 1997; Scuderi et al., 2006; Scalici and Gibertini, 2007), prey for different species (Slater and Rayner, 1993; Blake, 1995; Rodríguez et al., 2005), and supporting recreational and commercial activities worldwide (Hobbs et al., 1989; Holdich, 2002) including Central Italy (Dörr et al., 2001; Chiesa et al., 2006; Nonnis Marzano et al., 2009; Scalici et al., 2009a,c).

Providing more data on the ecology of exotic species may help to improve predictive models inferring their invasiveness, and may elucidate changes in life history occurring several years after introduction. Although a series of studies on population structure and dynamics have just been performed on crayfish, past long-term comparisons in demographic parameters usually focused only on trends in population size (e.g., Lodge et al., 1986, 1994; Wilson et al., 2004; Olden et al., 2006).

Here, we would like to contribute to this topic with a long-term study on one of the most commonly introduced crayfish worldwide (Souty-Grosset et al., 2006; Gherardi, 2006), the North-American red swamp crayfish Procambarus clarkii (Girard, 1852), whose introduction history in Europe and invasive ecology are well documented by Chucholl (2011). This species was recorded for the first time in Lake Trasimeno (Perugia, Central Italy) in 2000 (Dörr et al., 2001). In 2001, Dörr et al. (2006) studied the reproductive and population characteristics of the $P$. clarkii population, which seemed to be already well established at this time. 
The main aim of the present study was to re-investigate the population ecology of this $P$. clarkii population eight years later, in order to identify possible changes in its life-history traits. In particular, we discuss if the establishment of the population through time could have led to a change in some life-history traits such as molting stage, reproductive period, growth and mortality rates, and expected longevity. In addition, we discuss the life-history plasticity of $P$. clarkii throughout different European localities, thus providing a better understanding of its remarkable invasive strategy.

\section{MATERIALS AND METHODS}

\section{> SAMPLING DESIGN AND DATA COLLECTION}

Crayfish were collected monthly from June 2007 to July 2009 (except December 2007) by a professional fisherman over a 48-hour period using two fyke nets set at a depth of about $1.5 \mathrm{~m}$ and at a distance of $20 \mathrm{~m}$ from the shoreline. The sampling site (Trasimeno, the largest Italian peninsular lake, considered a SAC and SPA of Central Italy according to the EU Habitats Directive 92/43/EEC), sampling method, and catch effort were the same as 8 years before, as described by Dörr et al. (2006). Captured crayfish were immediately transported to the laboratory for further assessment. Each individual was sexed, measured from the tip of the rostrum to the posterior margin of the cephalothorax (CTL) by a digital caliper to the nearest $1 \mathrm{~mm}$, and weighed using an electronic balance to the nearest $0.1 \mathrm{~g}$. Molting state (soft or hard shell) was determined for both sexes. The crayfish shell was analyzed by touch and specimens with a soft exoskeleton were recorded as newly molted as well as those presenting slightly consumed gastroliths in their stomach.

\section{$>$ REPRODUCTIVE ASPECTS}

The sexual maturation pattern in $P$. clarkii males was assessed by recording the frequency of specimens with the reproductive phenotype (Form I) and those with a juvenile-like nonreproductive form (Form II) (Reynolds, 2002). Male reproductive phenotypes can be easily recognized by the presence/absence of the spines on the third and fourth walking legs. In particular, the presence of spines was observed in all adult males displaying mating behavior (Taketomi et al., 1990). All females were dissected to extract the gonads and hepato-pancreas to calculate the wet gonado-somatic index (GSI) and the wet hepato-somatic index (HIw):

$$
\begin{aligned}
& \mathrm{GSI}=[W g /(W b-W g)] \times 100 ; \\
& \mathrm{HIW}=(W h / W b) \times 100 ;
\end{aligned}
$$

where $W b, W g$ and $W h$ are the wet weight of the body, gonad and hepato-pancreas, respectively. A correlation analysis was performed between the two indices.

Deviation of the sex ratio from 1:1 and differences in molting frequency between sexes were analyzed for each sampling month using $\chi^{2}$ tests with Yates' correction.

\section{> POPULATION STRUCTURE AND DYNAMICS}

Although crustacean physiology is different from that of fish, their average body growth conforms with the von Bertalanffy (1938) growth model, allowing the length frequency approach (LFA) to be commonly applied to decapods (see Scalici et al., 2009b, and references therein). Therefore, we assessed several von Bertalanffy dynamic parameters (VBPs) using Electronic LEngth Frequency ANalysis (ELEFAN). Crayfish were grouped by sampling month and a total of $50 \mathrm{CTL}$ frequency distributions (25 per sex) were obtained from 2-mm CL interval size classes. 
We estimated the curvature parameter ( $\mathrm{k}$ ) from a plot of the fitted index, i.e. $R n=10^{\mathrm{ESP} / \mathrm{ASP}} / 10$, where $R n$ is the fit index for the scan of potential $k$ values in several simulations, ASP is the available sum of peaks, and ESP is the explained sum of peaks (for details see Gayanilo and Pauly 1997, and Sparre and Venema 1996). The highest $R n$ value observed in the diagrams corresponds to the estimated curvature parameter of the population. Applying ELEFAN to size frequencies compensates for the absence of more reliable data from skeletal structures used for teleosts, since in crayfish hard structures such as gastroliths are not reliable to age individuals (Scalici and Gibertini, 2009).

CTL data were used to generate polymodal distributions for the computation of the growth model applying the seasonalized von Bertalanffy equation (Pauly and Gauschutz, 1979):

$$
L(t)=L_{\text {inf }}\left\{1-\exp \left[-k\left(t-t_{0}\right)-(C k / 2 \pi)\left(\sin 2 \pi\left(t-t_{\mathrm{s}}\right)-\sin 2 \pi\left(t_{0}-t_{\mathrm{s}}\right)\right)\right]\right\}
$$

where $L(t)$ is the length at the age $t, L_{\text {inf }}$ is the asymptotic length (equal to $L_{\max } / 0.95$, where $L_{\max }$ is the maximum recorded length), $k$ is the curvature parameter, $t_{0}$ is the initial condition parameter (when specimens have $C T L=0$; although biologically meaningless, this represents an important component of the curve), $C$ is the amplitude of the curve (giving an estimate of the influence of seasonality on the growth trend), and $t_{\mathrm{s}}$ is the summer point (referring to the onset of the first oscillation relative to $t=0$ ). In this case, $t_{\mathrm{s}}$ is replaced by the winter point $\left(W p=t_{\mathrm{s}}+0.5\right)$, the season when the growth rate is the lowest within the annual cycle. For more details on all the above-mentioned dynamic parameters, see Beverton (1963), Pauly (1981), Sparre and Venema (1996), and Gayanilo and Pauly (1997).

Two other population parameters were considered: 1) the expected longevity from the formula $t_{\max }=3 / k$ (Gayanilo and Pauly, 1997), and 2) the total mortality index $Z$ (= natural mortality + fishing mortality) estimated by the Powell-Wetherall Plot equation (Powell, 1979; Wetherall, 1986) which computes $L_{\text {inf }}$ and the ratio $Z / k$. Natural mortality $(M)$ is correlated with $L_{\text {inf }}, \mathrm{k}$ and the mean water temperature by the following formula (Pauly, 1980):

$$
\log M=-0.0066-0.279 \log L_{\mathrm{inf}}+0.6543 \log k+0.463 \log T
$$

where $T$ is the mean water temperature recorded by the hydrological station of the Province of Perugia. $T$ showed the same trend for all three years with a maximum constantly between July and August (max. mean value $=26.41^{\circ} \mathrm{C}$ ) and a minimum constantly between December and January $\left(\mathrm{min}\right.$. mean value $=5.31^{\circ} \mathrm{C}$ ). The $T$ mean value determined for the study period was $16.77^{\circ} \mathrm{C}$.

Mortality due to fishing $(F)$ was then obtained by subtracting $M$ from $Z$.

Estimated VBPs were used to compare $P$. clarkii growth patterns, in particular to search for possible sexual dimorphism in the analyzed population. Then, we evaluated if the growth model of the Lake Trasimeno population changed (i.e., altered VBPs) after eight years by comparing our data with those of Dörr et al. (2006) using the Hotelling multivariate $T^{2}$-test as proposed by Bernard (1981) and Cerrato (1990) (see also Kovačić, 2006; Scalici et al., 2008b). As for the second comparison, we evaluated differences between the two periods, the present study and that of Dörr et al. (2006), only for the curvature parameter ( $k$ ) using the same test. Applying only the $k$ values was justified by the high correlation between $k$ and $L_{\text {inf }}\left(R^{2}\right.$ was always $\geqslant 0.73$, with $p$ always $\left.<0.05\right)$. This close relationship was evaluated after having performed 75 " $k$ vs. $L_{\text {inf }}$ " correlations using the procedure of Scalici et al. (2008b). In particular, we randomly extracted a sub-sample from the original length-frequency data, only to evaluate the " $k$ vs. $L_{\text {inf }}$ " relationship. The number of selected crayfish for each extraction amounted to $70-80 \%$ of the sum of collected and measured specimens. This allowed us to simulate the growth rate for a total of 75 populations for which we calculated the von Bertalanffy growth function. 


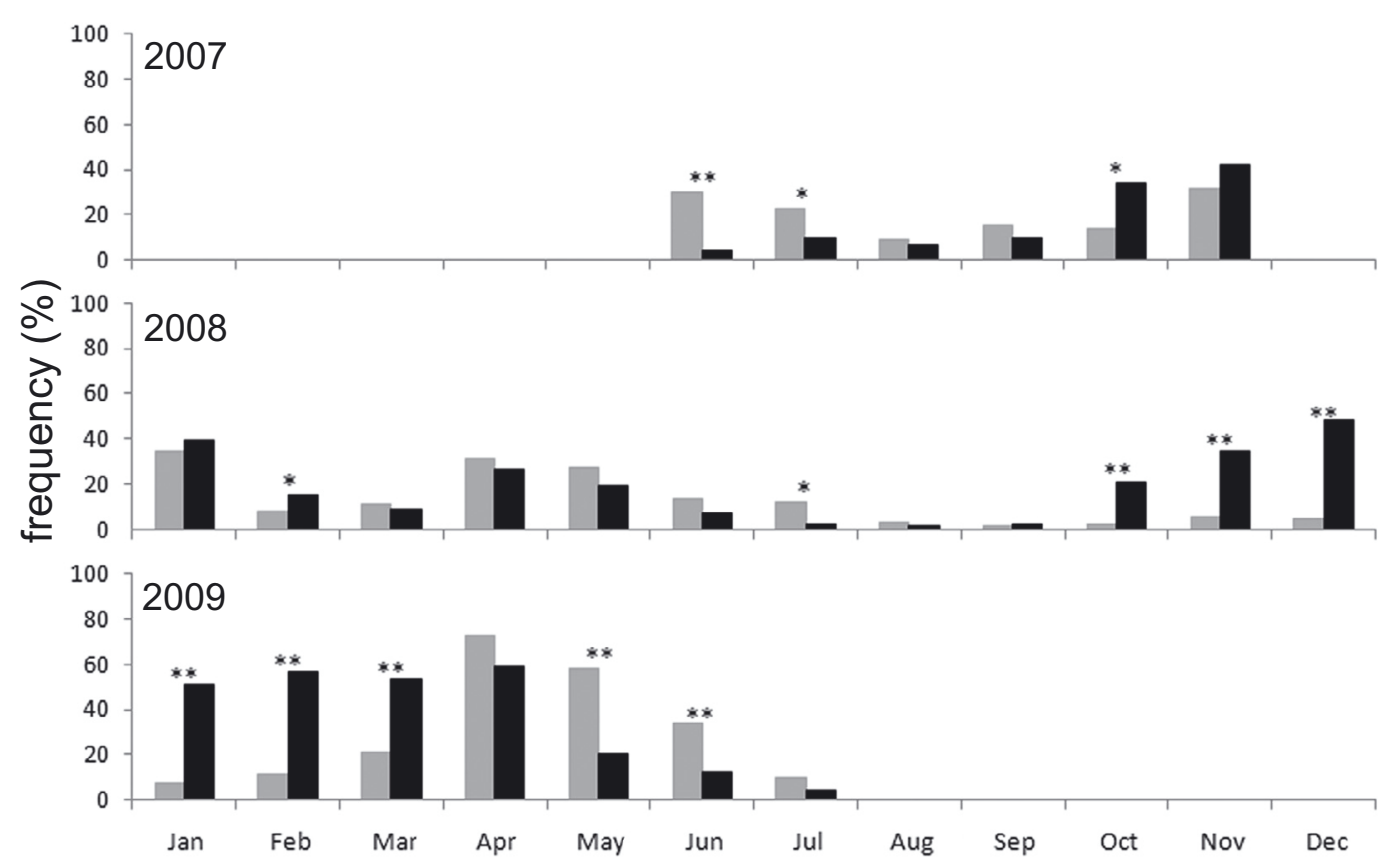

Figure 1

Fluctuation of molt (as percentage of 'soft-shelled' specimens) for both females (gray) and males (black). Asterisks represent differences between sexes: ${ }^{*}=P<0.05$; $^{* *}=P<0.01$.

\section{> STATISTICAL SOFTWARE}

Statistical analyses were performed using the FiSAT II (FAO-ICLARM Stock Assessment Tools) computer program (Gayanilo et al., 1996), R (ver. 2.15.2) and STATISTICA Statsoft software (ver. 6.0).

\section{RESULTS}

\section{> SAMPLE SIZE AND SEX RATIO}

A total of 3153 crayfish were collected during the sampling sessions in Lake Trasimeno: 1451 females and 1702 males. No berried females were collected during the study period. The sex ratio was 1:1 ( $p$ always $>0.05$ after the $\chi^{2}$ test with Yates' correction) except in October and November 2007, February, May, August and November 2008, and June 2009, always in favor of males $(p<0.05)$.

\section{> MOLTING PERIOD}

Molting frequencies showed some seasonal oscillations (Figure 1) for both sexes. Females molted more frequently than males in June and July 2007, July 2008, and May and June 2009. Remnant cases where differences occurred were in favor of males.

\section{> REPRODUCTIVE ASPECTS}

The percentage of males in the reproductive Form I was high for all sampling months (Figure 2), although there was some oscillation during the study period. The minimum was 65.91\% in December 2008, while the maximum 100\% occurred in July 2009. 


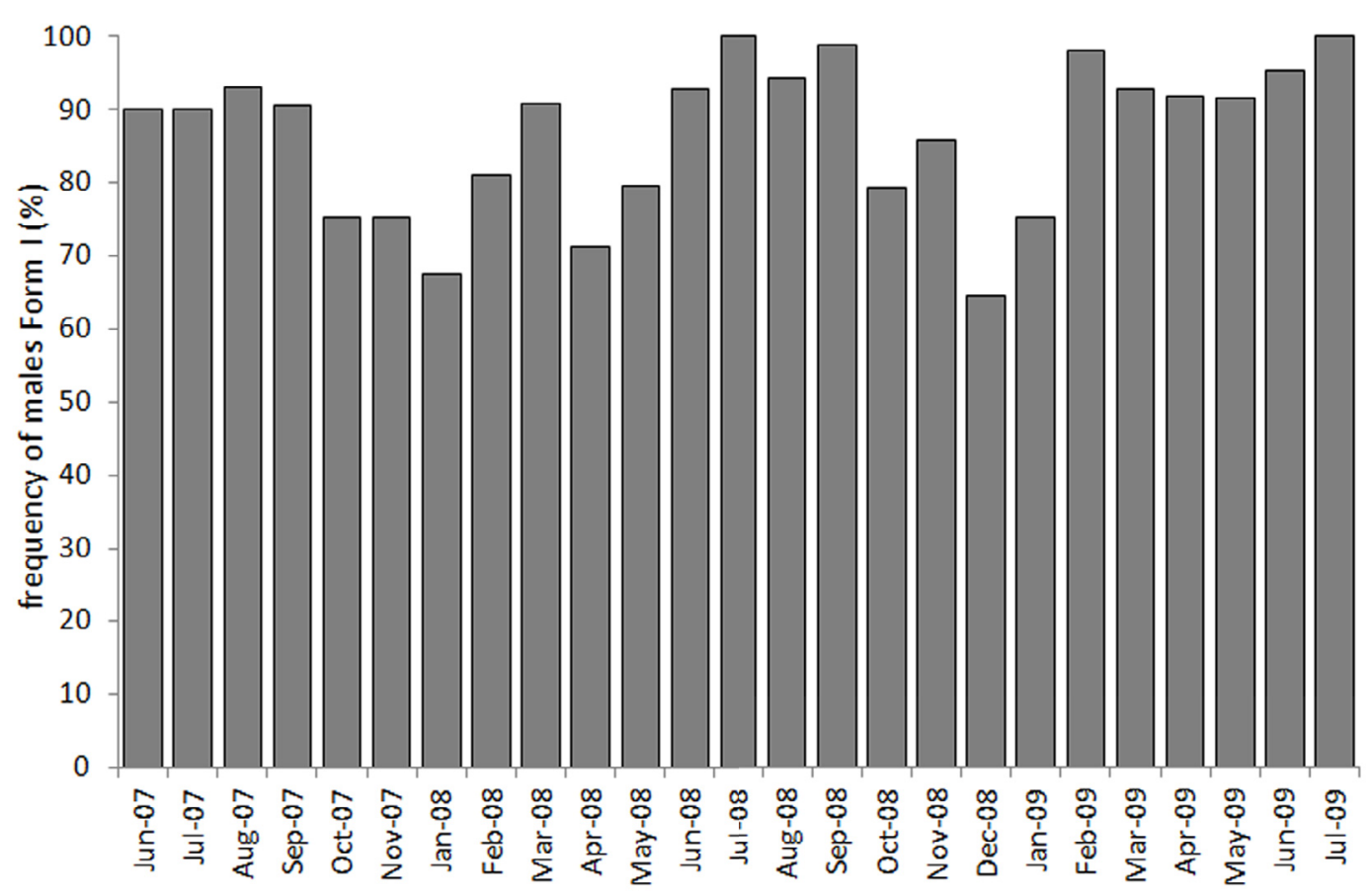

Figure 2

Frequency (expressed as percentage) of males with the reproductive phenotype Form I.

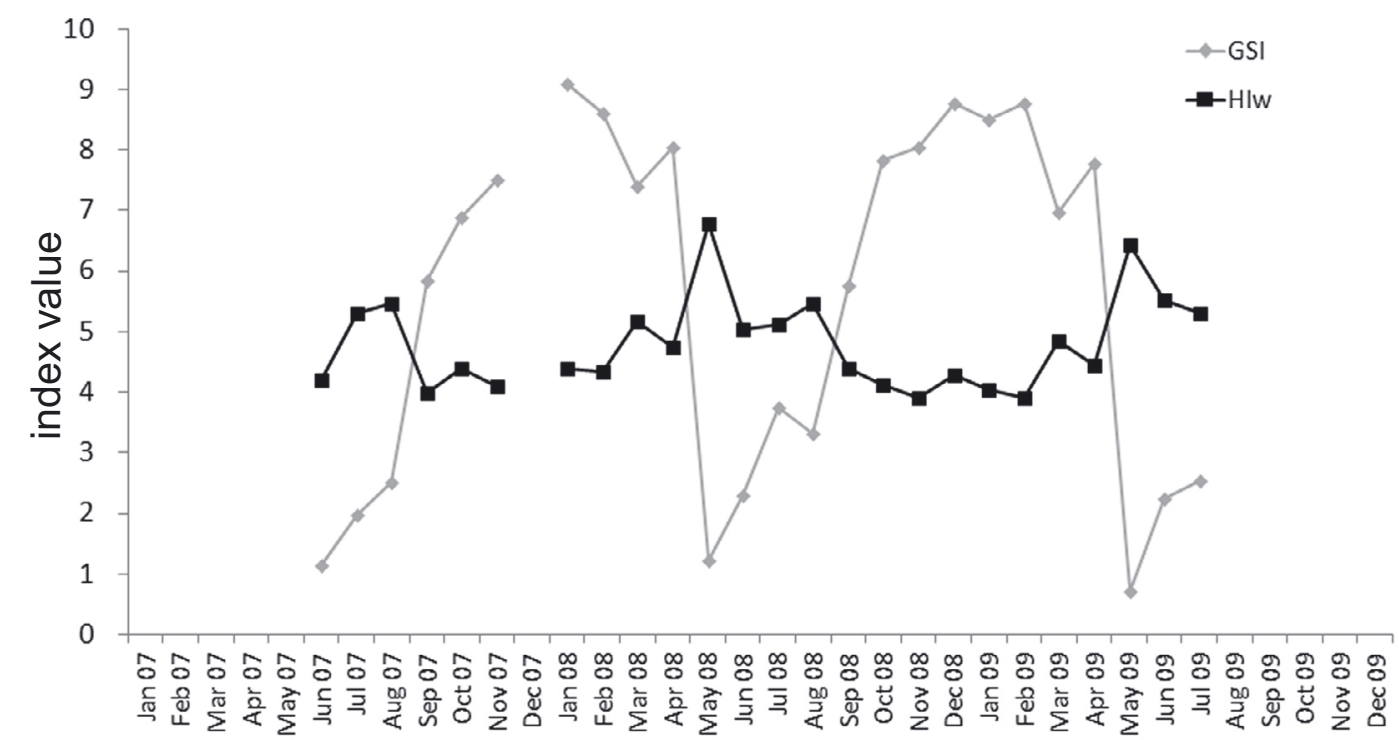

Figure 3

Mean value changes in the gonado-somatic index (GSI) and the wet hepato-somatic index (HIw) and the coefficient of their correlation $\left(R^{2}\right)$.

For females, both GSI and HIw $(N=1451)$ differed during the study period $\left(F_{24,6177}=24.33\right.$ and 19.77, respectively, both with $p<0.001)$. GSI was negatively correlated with $\mathrm{HIw}\left(R^{2}=\right.$ $0.84, p<0.01$ ) (Figure 3).

\section{> THE VON BERTALANFFY PARAMETERS AND THEIR DERIVATIVES}

From the analysis of the polymodal frequency distributions, 5-6 growth lines were observed in both sexes (Figure 4), each line corresponding to 1 year of age. The von Bertalanffy 


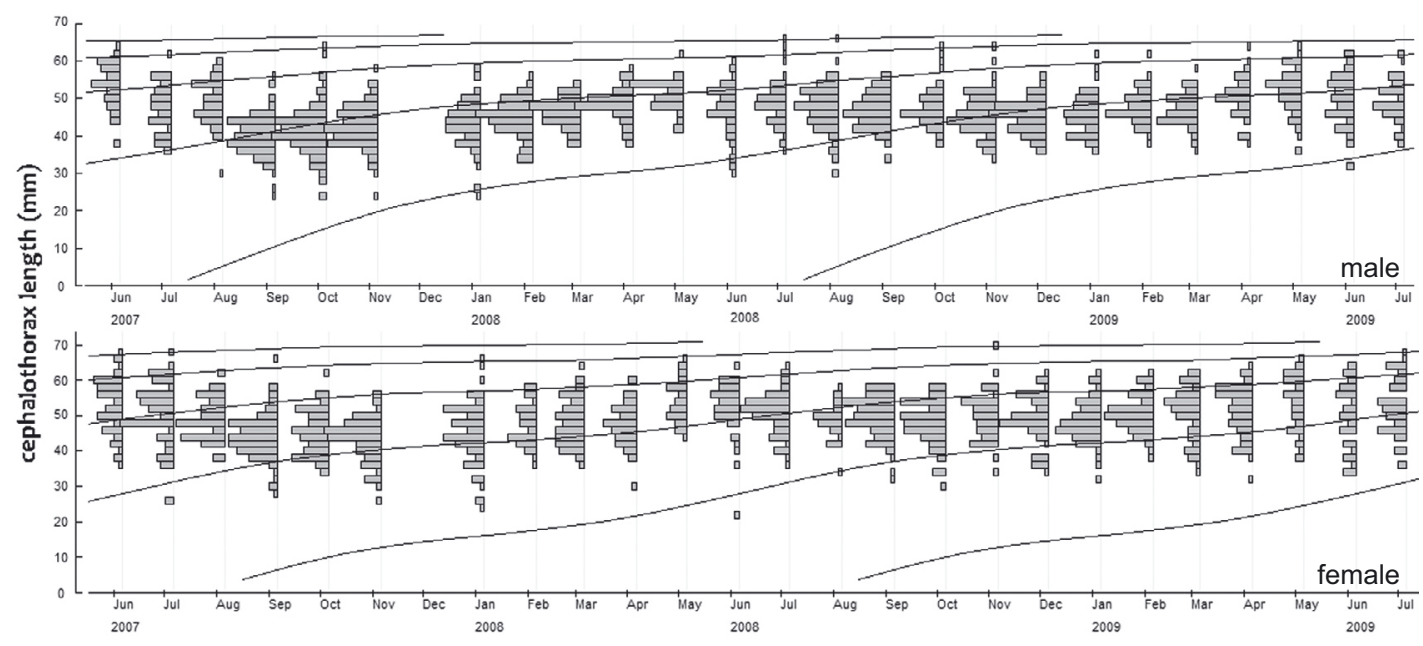

Figure 4

Growth models obtained by the electronic length frequency analysis (ELEFAN) distinguished per sex.

parameters ( $k$ and $L_{\text {inf }}$ ) and derivatives (i.e. $t_{0}, C, t_{\mathrm{s}}, W p, Z, M, F$ and $t_{\max }$ ) are given in Table I. The expected longevity ( $t_{\max }=5.17$ and 5.08 years for females and males, respectively) reflected the number of modal classes for both sexes. The mortality index $(Z)$ was high compared with other studies.

\section{$>$ COMPARISONS}

Series of pairwise Hotelling multivariate $T^{2}$-tests were performed to record possible sexual dimorphism in the growth pattern of the studied population, and the growth rate changes after 8 years after introduction (comparing our results with those obtained by Dörr et al., 2006).

As for the first comparison, no sexual dimorphism was observed in growth parameters of the Trasimeno population $\left(T_{\mathrm{ds}}^{2}<T_{0}^{2}, p>0.05\right)$, which was the same as recorded by Dörr et al. (2006) for the same population eight years earlier.

Regarding growth rates, the $\mathrm{k}$ values in this study were lower than those recorded by Dörr et al. (2006), for both females and males $\left(T_{\mathrm{ds}}^{2}>T_{0}^{2}, p<0.05\right.$, in both cases). As a consequence, all the remnant von Bertalanffy parameters changed accordingly.

\section{DISCUSSION}

\section{> POPULATION STRUCTURE}

Our life-history analysis was based on a large number of captured crayfish and included data from three consecutive years.

The P. clarkii population of Lake Trasimeno seems to be healthy, with a negligible number of injured individuals (pers. obs.), although some crayfish were found to be parasitized by several mycoflora species (Dörr et al., 2011, 2012a,b). Most specimens were sexually mature (i.e., with CTL > $21 \mathrm{~mm}$ for females and $24 \mathrm{~mm}$ for males, Huner, 2002; Scalici and Gherardi, 2007), indicating that the sampling nets were selective for individuals with CTL $>30 \mathrm{~mm}$. The catchable population was probably composed of crayfish which were at least one year old, which becomes apparent from the growth model as shown in Figure 4, where smaller size classes (probably $0+$ and $1+$ cohorts) are largely missing from the length frequency diagrams. The typical fyke nets adopted for Lake Trasimeno might render the catch per unit effort values (i.e., number of captured individuals per month using the standard sampling protocol) not 


\section{Table I}

Growth and dynamic parameters of the studied P. clarkii population, and others inhabiting European inland waters, reported in latitudinal order and divided per sex when possible. $C=$ ramplitude; $F=$ fishing mortality; $k=$ curvature parameter; $L_{\text {inf }}=$ asymptotic length; $M=$ natural mortality; $t_{0}=$ initial condition parameter; $t_{\max }=$ expected longevity; $t_{\mathrm{s}}=$ summer point; $W p=$ winter point; $Z=$ total mortality. ${ }^{*}=$ modified (i.e., re-elaborated) by the authors of the present study in order to obtain the Von Bertalanffy parameters divided per sex ( $f=$ female, and $m=$ male).

\begin{tabular}{|c|c|c|c|c|c|c|c|c|c|c|c|}
\hline & $\operatorname{sex}$ & k & $L_{\text {inf }}$ & $t_{0}$ & C & $t_{\mathrm{s}}$ & $W / p$ & $z$ & $M$ & $F$ & $t_{\max }$ \\
\hline $\begin{array}{l}\text { Chucholl (2011), Germany } \\
\text { freshwater lake I } \\
\left(48^{\circ} 27^{\prime} 32.4^{\prime \prime} \mathrm{N}, 10^{\circ} 10^{\prime} 32.3^{\prime \prime} \mathrm{E}\right)\end{array}$ & $\begin{array}{c}f \\
m\end{array}$ & $\begin{array}{l}0.45 \\
0.49\end{array}$ & $\begin{array}{l}79.8 \\
74.6\end{array}$ & $\begin{array}{l}-0.027 \\
-0.022\end{array}$ & - & $\begin{array}{l}- \\
-\end{array}$ & - & $\begin{array}{l}2.79 \\
2.26\end{array}$ & $\begin{array}{l}2.55 \\
2.26\end{array}$ & $\begin{array}{l}0.24 \\
0.00\end{array}$ & $\begin{array}{l}6.6 \\
6.1\end{array}$ \\
\hline $\begin{array}{l}\text { Scalici and Gherardi (2007), Italy } \\
\text { freshwater lake } \\
\left(43^{\circ} 48^{\prime} 01.4^{\prime \prime} \mathrm{N}, 10^{\circ} 47^{\prime} 38.2^{\prime \prime} \mathrm{E}\right)\end{array}$ & $\begin{array}{c}f \\
m\end{array}$ & $\begin{array}{l}0.68 \\
0.69\end{array}$ & $\begin{array}{l}65.5 \\
62.7\end{array}$ & $\begin{array}{l}-0.10 \\
-0.10\end{array}$ & $\begin{array}{l}0.37 \\
0.44\end{array}$ & $\begin{array}{l}-0.09 \\
-0.17\end{array}$ & $\begin{array}{l}0.41 \\
0.33\end{array}$ & $\begin{array}{l}4.94 \\
1.69\end{array}$ & $\begin{array}{l}4.89 \\
1.77\end{array}$ & $\begin{array}{l}0.05 \\
0.12\end{array}$ & $\begin{array}{l}4.57 \\
4.56\end{array}$ \\
\hline $\begin{array}{l}\text { Dörr et al. }(2006)^{\star} \text {, Italy } \\
\text { freshwater lake } \\
\left(43^{\circ} 08^{\prime} 45.6^{\prime \prime} \mathrm{N}, 12^{\circ} 06^{\prime} 31.4^{\prime \prime} \mathrm{E}\right)\end{array}$ & $\begin{array}{c}f \\
m\end{array}$ & $\begin{array}{l}0.89 \\
0.79\end{array}$ & $\begin{array}{l}81.3 \\
79.4\end{array}$ & $\begin{array}{l}-0.33 \\
-0.38\end{array}$ & $\begin{array}{l}0.51 \\
0.48\end{array}$ & $\begin{array}{l}-0.24 \\
-0.27\end{array}$ & $\begin{array}{l}0.22 \\
0.28\end{array}$ & $\begin{array}{l}5.20 \\
4.97\end{array}$ & $\begin{array}{l}2.91 \\
2.71\end{array}$ & $\begin{array}{l}2.29 \\
2.26\end{array}$ & $\begin{array}{l}3.37 \\
3.80\end{array}$ \\
\hline $\begin{array}{l}\text { present study, Italy } \\
\text { freshwater lake } \\
\left(43^{\circ} 08^{\prime} 45.6^{\prime \prime} \mathrm{N}, 12^{\circ} 06^{\prime} 31.4^{\prime \prime} \mathrm{E}\right)\end{array}$ & $\begin{array}{l}f \\
m\end{array}$ & $\begin{array}{l}0.58 \\
0.59\end{array}$ & $\begin{array}{l}73.71 \\
69.35\end{array}$ & $\begin{array}{l}-0.14 \\
-0.09\end{array}$ & $\begin{array}{l}0.51 \\
0.43\end{array}$ & $\begin{array}{l}-0.13 \\
-0.27\end{array}$ & $\begin{array}{l}0.37 \\
0.23\end{array}$ & $\begin{array}{l}5.10 \\
5.50\end{array}$ & $\begin{array}{l}2.77 \\
2.83\end{array}$ & $\begin{array}{l}2.33 \\
2.67\end{array}$ & $\begin{array}{l}5.17 \\
5.08\end{array}$ \\
\hline $\begin{array}{l}\text { Chiesa et al. }(2006)^{\star} \text {, Italy } \\
\text { freshwater lake } \\
\left(42^{\circ} 07^{\prime} 20.7^{\prime \prime} \mathrm{N}, 12^{\circ} 43^{\prime} 03.6^{\prime \prime} \mathrm{E}\right)\end{array}$ & $\begin{array}{c}f \\
m\end{array}$ & $\begin{array}{l}0.70 \\
0.66\end{array}$ & $\begin{array}{l}64.3 \\
63.3\end{array}$ & $\begin{array}{l}-0.10 \\
-0.10\end{array}$ & $\begin{array}{l}0.33 \\
0.26\end{array}$ & $\begin{array}{l}-0.28 \\
-0.16\end{array}$ & $\begin{array}{l}0.22 \\
0.34\end{array}$ & $\begin{array}{l}4.07 \\
3.83\end{array}$ & $\begin{array}{l}2.17 \\
1.94\end{array}$ & $\begin{array}{l}1.90 \\
1.89\end{array}$ & $\begin{array}{l}4.13 \\
4.45\end{array}$ \\
\hline $\begin{array}{l}\text { Scalici et al. (2010), Italy } \\
\text { brackish wetland } \\
\left(41^{\circ} 57^{\prime} 35.3^{\prime \prime} \mathrm{N}, 12^{\circ} 02^{\prime} 56.1^{\prime \prime} \mathrm{E}\right)\end{array}$ & $\begin{array}{c}f \\
m\end{array}$ & $\begin{array}{l}0.32 \\
0.33\end{array}$ & $\begin{array}{l}74.6 \\
68.3\end{array}$ & $\begin{array}{l}-0.43 \\
-0.37\end{array}$ & $\begin{array}{l}0.38 \\
0.33\end{array}$ & $\begin{array}{l}-0.14 \\
-0.21\end{array}$ & $\begin{array}{l}0.36 \\
0.29\end{array}$ & $\begin{array}{l}3.11 \\
2.88\end{array}$ & $\begin{array}{l}1.77 \\
1.63\end{array}$ & $\begin{array}{l}1.34 \\
1.25\end{array}$ & $\begin{array}{l}8.95 \\
8.73\end{array}$ \\
\hline $\begin{array}{l}\text { Chiesa et al. (2008), Italy } \\
\text { freshwater lake } \\
\left(41^{\circ} 42^{\prime} 04.6^{\prime \prime} \mathrm{N}, 13^{\circ} 41^{\prime} 11.3^{\prime \prime} \mathrm{E}\right)\end{array}$ & $\begin{array}{l}f \\
m\end{array}$ & $\begin{array}{l}0.71 \\
0.70\end{array}$ & $\begin{array}{l}66.2 \\
61.4\end{array}$ & $\begin{array}{l}-0.15 \\
-0.23\end{array}$ & $\begin{array}{l}0.42 \\
0.44\end{array}$ & $\begin{array}{l}-0.10 \\
-0.16\end{array}$ & $\begin{array}{l}0.40 \\
0.44\end{array}$ & $\begin{array}{l}3.54 \\
3.88\end{array}$ & $\begin{array}{l}2.57 \\
2.80\end{array}$ & $\begin{array}{l}0.97 \\
1.08\end{array}$ & $\begin{array}{l}4.11 \\
4.09\end{array}$ \\
\hline $\begin{array}{l}\text { Fidalgo et al. (2001), Portugal } \\
\text { lagoon } \\
\left(40^{\circ} 40^{\prime}-^{\prime \prime} N, 08^{\circ} 40^{\prime}-^{\prime \prime} W\right)\end{array}$ & - & 0.23 & 62.0 & - & - & - & - & - & - & - & 12.93 \\
\hline $\begin{array}{l}\text { Anastácio and Marques (1995), } \\
\text { Portugal } \\
\text { lowland river } \\
\left(40^{\circ} 10^{\prime}-^{\prime \prime} \mathrm{N}, 08^{\circ} 41^{\prime}-^{\prime \prime} \mathrm{E}\right)\end{array}$ & - & 0.68 & 56.0 & - & - & - & - & - & - & - & 4.29 \\
\hline 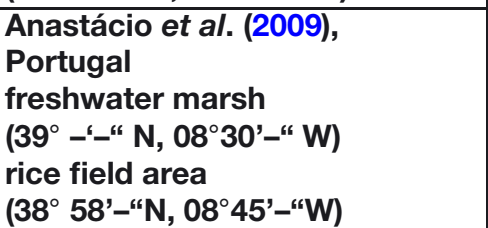 & - & $\begin{array}{l}1.32 \\
0.95\end{array}$ & $\begin{array}{l}74.8 \\
55.0\end{array}$ & - & - & - & - & $\begin{array}{l}3.99 \\
2.43\end{array}$ & - & - & $\begin{array}{l}2.27 \\
3.16\end{array}$ \\
\hline
\end{tabular}

comparable with those recorded for other Italian regions and European countries (see Scalici et al., 2010), but keep the bias constant all sampling period long. Furthermore, a different sampling design may create some kind of bias while evaluating the population dynamics properties, since tools (traps) and methods (location and duration of trapping) may affect the crayfish sampling. They may be selective for size classes (overall for adults), or could alter the crayfish behavior, and consequently their catchability (Somers and Stechey, 1986; Fjälling, 1995). Therefore, samples with less than 200 individuals may create problems during the extrapolation of the population structure and dynamics, when performing a polymodal length frequency analysis (France et al., 1991). This impasse can be avoided by performing long sampling series (Scalici et al., 2008a) as carried out for this study, for which we used the same methods as eight years earlier.

The sex ratio of the analyzed population varied markedly during the study period. When it differed from 1:1, the sex ratio was always in favor of males, in particular in October and November 2007, February, May, August and November 2008, and June 2009. Females never significantly prevailed over males, the opposite of what Dörr et al. (2006) reported for the same 


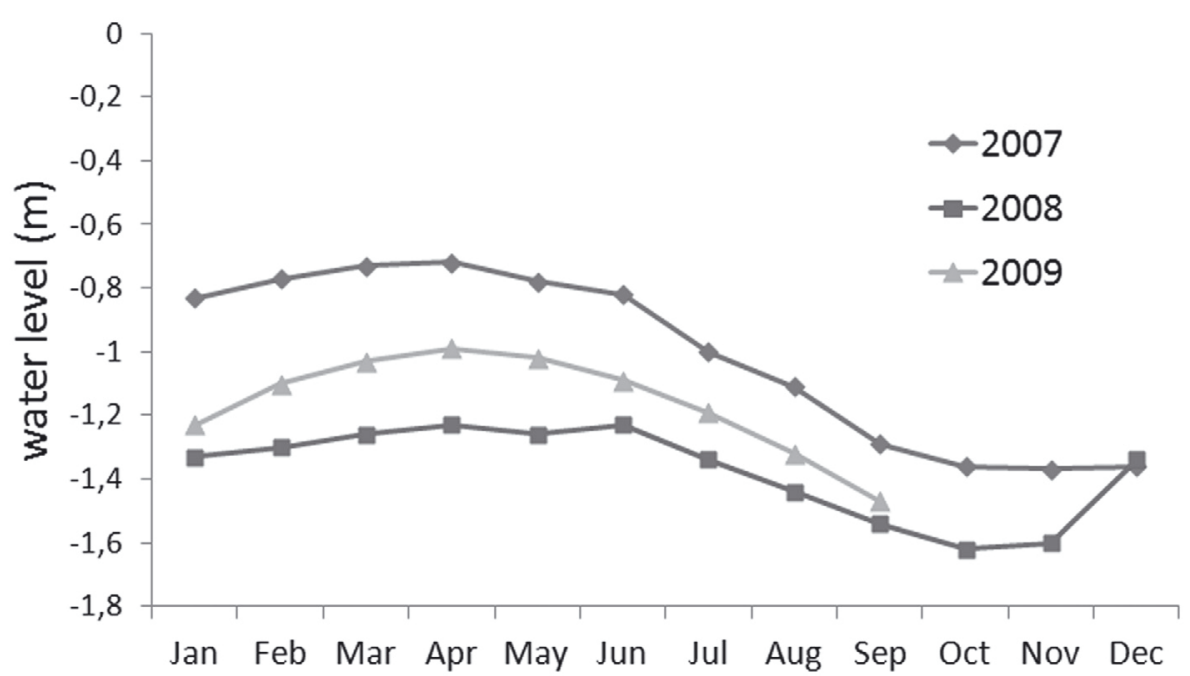

Figure 5

Mean values of the water level trend in Lake Trasimeno recorded by the hydrological station of the province of Perugia during the study period.

P. clarkii population in Lake Trasimeno eight years before. Although it is possible to expect a sex ratio (derived from trap data) biased towards males, there is a considerable variability on this topic in the literature (i.e. Oluoch, 1990; Anastácio and Marques, 1995; Costa et al., 1996; Gutiérrez-Yurrita et al., 1996; Frutiger et al. 1999; Pérez-Bote et al., 2000; Fidalgo et al., 2001; Scalici and Gherardi, 2007; Ligas, 2008). It is difficult to explain these results of the present study, since the sex ratio may differ depending on (1) water depth (Oluoch, 1990) and (2) the berried female burrowing habit (Huner, 2002). Anastácio and Marques (1995) proposed an increase in the proportion of females within populations with increasing latitude, as a response to unfavorable climates. Probably the prevalence of males in our study means favorable conditions and the studied population has reached a stable structure. The stability of the studied population seems to be confirmed by the high percentage of reproductive males. This percentage may provide information on the reproductive status according to Huner and Romaire (1979), who considered sexual maturation to assess habitat stability. Anyway, elucidations on mechanisms controlling the sex ratio oscillation seem to remain elusive.

\section{> MOLTING PERIOD AND REPRODUCTIVE ASPECTS}

Females and males differed in the frequency of occurrence of soft crayfish, although they seem to show the same molting period. Crayfish molted from the end of fall to the beginning of summer, with males being more active in winter than females. This elevated molting activity in males may explain the high portion of Form I individuals, since males have to molt in order to change their reproductive status (Taketomi et al., 1990). The molting activity was very low in August and September for both sexes. Dörr et al. (2006) described a converse phenomenon with a molting period restricted for both sexes to spring, the peak of the activity. The extension of the molting period found in this study may be due to the general water level drawdown throughout the years (cf. Figure 5, and AJMD, pers. data) and the subsequent temperature increase (cf. data in Dörr et al., 2006), since the temperature increase positively affects the molting rate (Reynolds, 2002). The reproductive status of both sexes was examined separately, since we did not find direct links between the reproductive states of the two sexes. During the study period we did not collect berried females, probably because of their habit of hiding in burrows. In our study, males did not seem to provide information for understanding the extension of the reproductive period, since a high percentage of Form I males can be observed during the year, although some reduction occurred during fall. For females, 
both reproductive indices indicated a high ovarian and a low hepato-pancreatic (involved in vitellogenesis) activity from October to April, with the probable emission of eggs between April and May. In contrast, Dörr et al. (2006) described the maximum ovarian egg maturation at the end of the summer for the same population. This shift of 5-6 months is difficult to explain, because reproduction and egg incubation vary across $P$. clarkii' populations (Scalici and Gherardi, 2007; Ligas, 2008), depending on different environmental features, such as temperature, habitat and food resources. In our case, a possible explanation could regard the lake water level management (Hitoshi and Toshiki, 1998). The increased water depth in November/December may have enhanced the lake's productivity and consequently food availability, and thus could have influenced the gamete production.

\section{> POPULATION DYNAMICS}

Although dynamic parameters seem to show some differences to those recorded by Dörr et al. (2006), habitat features continue to be adequate for the regular growth of the investigated population.

Analysis of von Bertalanffy's parameters did not seem to support the results of previous studies on other European populations and may be due to the sampling design adopted in the different study areas (see bias description above). Differences in life history among European populations (Table I) may also be due to diverse ecological conditions, crayfish being temperature-sensitive (see Reynolds, 2002). This sensitivity can cause a great variability in the von Bertalanffy growth parameters and derivates (Chucholl, 2011).

The comparison between the currently and previously studied population in Lake Trasimeno leads to a consideration of the effect of fishing pressure on invasive species. Fishing activities might control invasive populations, as proposed by other authors (see below). Therefore, population structure and dynamics can become an essential instrument in the management of aquatic living resources, since they can be used in the evaluation of population status. Thus, in general, we may be able to describe eventual changes in life-history patterns mainly due to human activities, and, for instance, we may carefully plan an overfishing strategy against alien species. This is based on the principle that a stock decline due to irrational exploiting is also valid for alien species and, thus, allows control of such species (Anastacio and Marques, 1995; Scalici and Gibertini, 2002; Hein et al., 2007; Gherardi et al., 2008). The recorded mortality rate values seem to confirm that the red swamp crayfish in Lake Trasimeno is overexploited (see Dörr et al. (2006). The professional fishermen activity seems to be able to control the $P$. clarkii population. This high fishing pressure may facilitate the establishment of a low crayfish density and consequently lead to a high body growth rate (see below). We have no data on the population size modification through time, and are aware that this topic may be speculative, although data on the fishing mortality support this opinion well. Anyway, in order to solve this question, more studies ought to be performed to understand the real crayfish population size oscillations in Lake Trasimeno.

Length-frequency analysis confirmed the stable structure of our crayfish population with a clearly defined age-class composition of slightly more than five age classes for both females and males. The number of age classes can vary in number across $P$. clarkii populations, from the three described by Lozano-Guerra and Escamilla-Niño (1995), Chiesa et al. (2006), and Ligas (2008), to up to five described by Huner (2002).

The maximum expected longevity $\left(t_{\max }\right)$ we recorded was around 5 years for both sexes, and is confirmed by the number of lines (age classes) we observed for the population analysis. These values are similar to other evaluations proposed in the literature for freshwater systems. Huner (2002), and Scalici and Gherardi (2007) maintain that the lifespan of $P$. clarkii has a maximum duration of 4 years, while Frutiger et al. (1999) and Chucholl (2011) described that the bigger specimens could live for around 5 and more than 6 years, respectively. Since temperature can greatly affect the VBPs, it seems to be important to underline that Frutiger et al. (1999) worked on a population in Switzerland at higher latitude. 


\section{> LONG-TERM DATA COMPARISON}

Although invasive crayfish are unwanted species, they can provide useful study animals for the elaboration of evolutionary and ecological models (e.g., Barbaresi et al., 2003; Dörr et al., 2011, 2012a,b; Filipová et al., 2010), concerning mainly the founder effect and colonization patterns.

Long-term differences in the life history registered for the Lake Trasimeno population and differences among $P$. clarkii populations in the literature (Table I) may also result from environmental variations which can stress the population and induce changes in some dynamic properties. Our results showed that, in contrast to 8 years ago, but similarly to other populations, $P$. clarkii maintained a relatively high growth rate. The curvature parameter values of the latter are typical of a tendentially r-selected species, although the studied population exhibits a decrease in the curvature parameter value, when compared with the results of Dörr et al. (2006). From values of 0.85 the red swamp crayfish decreased its growth, becoming similar to those of other populations. Sakai et al. (2001) proposed that characteristics common to successful colonists across taxa include r-selected life histories (exploitation of pioneer habit, short generation time, high fecundity and high growth rates) and their ability to shift between $r$ - and $k$-selected strategies. This is particularly true for $r$-selected species (having a wide ecological spectrum, such as $P$. clarkii) which are able to resist different stressors or limiting factors.

This does not exclude the hypothesis that $P$. clarkii in Lake Trasimeno could be influenced by the Allee effect, which is characterized by some kind of non-linearity in dynamics (see Courchamp et al., 1999; Stephens and Sutherland, 1999). This phenomenon is due to some kind of population threshold (represented by several biological and non-biological factors) below which the population growth rate becomes negative, and above which the population growth rate becomes positive (Dennis, 1989, 2002; Stephens and Sutherland, 1999).

If, on one hand, the Allee effect is commonly related to the population abundance, this effect may also affect the body growth rate. Although no evidence was found for crayfish in the literature, some authors stated that relationships between body size and population abundance exist. Indeed, Jobling (1985) found a close relationship between density and body size in the Arctic charr Salvelinus alpinus reared in controlled conditions. Therefore although this aspect remains speculative (due to the lack of data from the Lake Trasimeno crayfish population), we may argue that the demographic growth rate of the studied crayfish population may have affected the body growth rate. In particular, after its introduction, the low population density values may have guaranteed to crayfish more food availability and a minor predation pressure by native species. As a result, crayfish are supplied by a larger amount of food and can attain a higher individual growth rate. When the demographic growth rate assumes higher values, population density increases and, consequently, a decline in food availability might occur. Limited food availability may then cause a lower individual growth rate. This may lead to low body growth values as body size represents one of the most fundamental properties of an organism, being related to many biological traits, including population abundance (see White et al., 2007)

Unfortunately, we currently know little about the prevalence, the evolutionary and ecological causes, and the consequences of life-history plasticity in the wild (Nussey et al., 2007). It appears likely that the lag time between initial colonization and the onset of rapid population growth and range expansion could be a result of the time required for adaptation to overcome some environmental constraints (Mack et al., 2000) depending on different factors, such as climate, food availability, predator pressures, altitude, hydric regime, density, competition and human exploitation (Momot et al., 1978; Aiken and Waddy, 1992; Jones and Coulson, 2006; Ramalho et al., 2008).

The life pattern change of the studied $P$. clarkii population may also be due to human water use where the crayfish live. The natural hydropattern and seasonal functioning of the Lake Trasimeno have been drastically altered by the excessive drawdown of water for urban and agricultural uses over the past half century. It is known that changes in hydropatterns can 
affect some population properties, such as for P. clarkii in Spain (Alcorlo et al., 2008) and Portugal (Anastácio et al., 2009).

There is considerable scope for further work on the influence of environmental factors on the life history of non-indigenous crayfish species. New habitat colonization, changing growth patterns, molt increment and frequency due to climate changes, human water use and fishing pressure, and their synergistic effect on alien crayfish have not yet been exhaustively studied.

\section{ACKNOWLEDGEMENTS}

We are indebted to the reviewers, and Professor Andrew Boulton for their useful suggestions toward improvement of the manuscript. We would like to thank Mrs. Orietta and the professional fishermen of the Cooperativa Alba del Lago Trasimeno for their kind assistance during the 2-year sampling period, and last but not least, Dr. Nicole Pacini for her proficient contribution in the laboratory. The experiments were conducted in accordance with the European and national guidelines (European Commission, Directive 86/609/EC and Italian Directive 116/1992, respectively).

\section{REFERENCES}

Aiken D.E. and Waddy S.L., 1992. The growth process in crayfish. Rev. Aquat. Sci., 6, 335-381.

Anastácio P.M. and Marques J.C., 1995. Population biology and production of the red swamp crayfish Procambarus clarkii (Girard) in the lower Mondego river valley, Portugal. J. Crustacean Biol., 15, 156-168.

Alcorlo P., Geiger W. and Otero M., 2008. Reproductive biology and life cycle of the invasive crayfish Procambarus clarkii (Crustacea: Decapoda) in diverse aquatic habitats of South-Western Spain: Implications for population control. Fund. Appl. Limnol., 173, 197-212.

Anastácio P.M., Leitão A.S., Boavida M.J. and Correia A.M., 2009. Population dynamics of the invasive crayfish (Procambarus clarkii Girard, 1852) at two marshes with differing hydroperiods. Intern. J. Limnol., 45, 247-256.

Barbaresi S., Fani R., Gherardi F., Mengoni A. and Souty-Grosset C., 2003. Genetic variability in European populations of an invasive American crayfish: preliminary results. Biol. Invasions, 5, 269-274.

Bernard D.A., 1981. Multivariate analysis as a means of comparing growth in fish. Can. J. Fish. Aquat. Sci., 38, 233-236.

Beverton R.J.H., 1963. Maturation, growth and mortality of clupeid and engraulid stocks in relation to fishing. J. Coun. CIEM, 154, 44-67.

Blake M.A., 1995. The vulnerability of juvenile signal crayfish to perch and eel predation. Freshw. Biol., 33, 233-244.

Burlakova L.E., Padilla D.K., Karatayev A.Y., Hollas D.N., Cartwright L.D. and Nichol K.F., 2010. Differences in population dynamics and potential impacts of a freshwater invader driven by temporal habitat stability. Biol. Invasions, 12, 927-941.

Capinha C., Leung B. and Anastácio P., 2011. Predicting worldwide invasiveness for four major problematic decapods: an evaluation of using different calibration sets. Ecography, 34, 448-459.

Cerrato R.M., 1990. Interpretable statistical tests for growth comparisons using parameters in the von Bertalanffy equation. Can. J. Fish. Aquat. Sci., 47, 1416-1426.

Chiesa S., Scalici M. and Gibertini G., 2006. Occurrence of allochthonous freshwater crayfishes in Latium (Central Italy). Knowl. Managt. Aquatic Ecosyst., 380-381, 83-902.

Chiesa S., Celauro D., Scalici M., Monaco A., Scalisi M. and Gibertini G., 2008. II gambero rosso della Louisiana Procambarus clarkii nella Riserva Naturale Regionale "Lago di Posta Fibreno": problematiche di gestione e priorità di azione per il futuro. Atti della prima giornata di studio "Tutela e conservazione dell'ecosistema acquatico Lago di Posta Fibreno area SIC/ZPS IT6050015", Università degli Studi "La Sapienza", Orto Botanico, 100-118. 
Chucholl C., 2011. Population ecology of an alien "warm water" crayfish (Procambarus clarkii) in a new cold habitat. Knowl. Managt. Aquatic Ecosyst., 401, 29.

Costa A.C., Correia A.M. and Rodrigues M.L., 1996 Monitoring a population of Procambarus clarkii in São Miguel (Azores, Portugal). Freshw. Crayfish, 11, 203-212.

Courchamp F., Clutton-Brock T. and Grenfell B., 1999. Inverse density dependence and the Allee effect. Trends Ecol. Evol., 14, 405-410.

DAISIE 2009. Handbook of alien species in Europe. Springer, Dordrecht, Netherlands.

Dennis B., 1989. Allee-effects: population growth, critical density, and the chance of extinction. Nat. Res. Model., 3, 481-538.

Dennis B., 2002. Allee effects in stochastic populations. Oikos, 96, 389-401.

Dörr A.J.M., Pedicillo G. and Lorenzoni M., 2001. Prima segnalazione in Umbria di Procambarus clarkii (Girard), Orconectes limosus (Rafinesque) e Astacus leptodactylus Eschscholtz (Crustacea Decapoda). Riv. Idrobiol. , 40, 221-233.

Dörr A.J.M., La Porta G., Pedicillo G. and Lorenzoni M., 2006. Biology of Procambarus clarkii (Girard, 1852) in Lake Trasimeno. Knowl. Managt. Aquatic Ecosyst., 380-381, 1155-1168.

Dörr A.J.M., Rodolfi M., Scalici M., Elia A.C., Garzoli L. and Picco A.M., 2011. Phoma glomerata, a potential new threat to Italian inland waters. J. Nat. Conserv., 19, 370-373.

Dörr A.J.M., Elia A.C., Rodolfi M., Garzoli L., Picco A.M., D’Amen M. and Scalici M., $2012 a$. A model of co-occurrence: segregation and aggregation patterns in the mycoflora of the crayfish Procambarus clarkii in Lake Trasimeno (central Italy). J. Limnol., 71, 135-143.

Dörr A.J.M., Rodolfi M., Elia A.C., Scalici M., Garzoli L. and Picco A.M., 2012b. Mycoflora on the cuticle of the invasive species of the crayfish Procambarus clarkii. Fund. Appl. Limnol., 180, 77-84.

Ezard T.H.G., Bullock J.M., Dalgleish H.J., Millon A., Pelletier F., Ozgul A. and Koons D.N., 2010. Matrix models for a changeable world: the importance of transient dynamics in population management. J. Appl. Ecol., 47, 515-523.

Fidalgo M.R.A., Carvalho P. and Santos P. 2001. Population dynamics of the red swamp crayfish, Procambarus clarkii (Girard, 1852) from the Averio Region, Portugal (Decapoda, Cambaridae). Crustaceana, 74, 369-375.

Filipová L., Holdich D.M., Lesobre J., Grandjean F. and Petrusek A., 2010. Cryptic diversity within the invasive virile crayfish Orconectes virilis (Hagen, 1870) species complex: new lineages recorded in both native and introduced ranges. Biol. Invasions, 12, 983-989.

Fjälling, A., 1995. Crayfish traps employed in Swedish fisheries. Freshw. Crayfish, 8, 201-214.

Frutiger A., Borner S., Büsser T., Eggen R., Müller R., Müller S. and Wasmer H.R., 1999. How to control unwanted populations of Procambarus clarkii in Central Europe? Freshw. Crayfish, 12, 714-726.

Gayanilo F.C. Jr and Pauly D., 1997. FAO ICLARM stock assessment tools. Reference manual. FAO Computerized Information Series, Fisheries, Rome, 262 p.

Gayanilo F.C. Jr., Sparre P. and Pauly D., 1996. The FAO ICLARM stock assessment tools (FiSAT) user's guide. FAO Computerized Information Series, Fisheries, Rome, 126 p.

Gherardi F., 2006. Crayfish invading Europe: the case study of Procambarus clarkii. Mar. Freshw. Behav. Physiol., 39, 175-191.

Gherardi F., Bertocchi S., Brusconi S., Giorgi G., Tricarico E. and Parisi G., 2008. Da invasore a risorsa: il caso del gambero "killer". Dipartimento di Biologia Animale e Genetica e Dipartimento di Scienze Zootecniche dell'Università degli Studi di Firenze.

Gollasch S. and Leppäkoski E., 1999. Initial risk assessment of alien species in Nordic coastal waters, Nordic Council of Ministers, Copenhagen.

Gutiérrez-Yurrita P.J., Ilhéu M., Montes C. and Bernardo J., 1996. Morphometrics of red swamp crayfish from a temporary Marsh (Doñana National Park, Sw. Spain) and a temporary stream (Pardiela stream, S. Portugal). Freshw. Crayfish, 11, 384-393.

Hein C., Vander Zanden M.J., and Magnuson J.J., 2007. Intensive trapping and increased fish predation cause massive population decline of an invasive crayfish. Freshw. Biol., 52, 1134-1146.

Hitoshi A. and Toshiki M., 1998. Structure of the ovary and mode of oogenesis in a freshwater crayfish Procambarus clarkii (Girard). Zool. Sci., 15, 893-901.

Hobbs H.H., Jass J.P. and Huner J.V., 1989. A review of global crayfish introductions with particular emphasis on two North American species (Decapoda, Cambaridae). Crustaceana, 56, 299-316. 
Holdich D.M., 2002. Biology of freshwater crayfish, Blackwell Science, Oxford, 702 p.

Huffaker C.B., Berryman A.D. and Laing J.E., 1984. Natural control of insect populations. In: Huffaker C.B. and Rabb R.L. (eds.), Ecological entomology. Wiley, New York, 359-398.

Huner J.V., 2002. Procambarus. In: Holdich D.M. (ed.), Biology of freshwater crayfish, Blackwell, Oxford, 541-584.

Huner J.V. and Romaire R.P., 1979. Size at maturity as means of comparing populations of Procambarus clarkii (Girard) (Crustacea, Decapoda) from different habitats. Freshw. Crayfish, 4, 53-64.

Jobling M., 1985. Physiological and social constraints on growth of fish with special reference to Arctic charr, Salvelinus alpinus L. Aquaculture, 44, 83-90.

Jones J.P.G. and Coulson T., 2006. Population regulation and demography in a harvested freshwater crayfish from Madagascar. Oikos, 112, 602-611.

Kovačić M., 2006. Age structure, growth and mortality of the striped goby, Gobius vittatus (Gobiidae) in the northern Adriatic Sea. Sci. Mar., 70, 635-641.

Krebs C.J., 2002. Beyond population regulation and limitation. Wildl. Res., 29, 1-10.

Ligas A., 2008. Population dynamics of Procambarus clarkii (Girard, 1852) (Decapoda, Astacidea, Cambaridae) from southern Tuscany (Italy). Crustaceana, 81, 601-609.

Lodge D.M., Kratz T.K. and Capelli G.M., 1986. Long-term dynamics of three crayfish species in Trout Lake, Wisconsin. Can. J. Fish. Aquat. Sci., 43, 993-998.

Lodge D.M., Kershner M.W., Aloi J.E. and Covich A.P., 1994. Effects of an omnivorous crayfish (Orconectes rusticus) on a freshwater littoral food web. Ecology, 75, 1265-1281.

Lozano-Guerra J. and Escamilla-Niño A., 1995. Ecology of red swamp crayfish (Procambarus clarkii, Girard) in the Central Meseta of Spain. Freshw. Crayfish, 8, 179-200.

Mack R.N., Simberloff D., Lonsdale W.M., Evans H,. Clout M. and Bazzaz F.A. 2000. Biotic invasions: causes, epidemiology, global consequences, and control. Ecol. Appl., 10, 689-710.

Momot W.T., 1995. Redefining the role of crayfish in aquatic ecosystems. Rev. Fish. Sci., 3, 33-63.

Momot W.T., Gowing H. and Jones P.D., 1978. The dynamics of crayfish and their role in ecosystems. Am. Midl. Nat., 99, 10-35.

Murray B.G. Jr., 1979. Population dynamics: alternative models, Academic Press, New York.

Nonnis Marzano F., Scalici M., Chiesa S., Gherardi F. and Gibertini G., 2009. The first record of the marbled crayfish adds further threats to fresh water in Italy. Aquat. Inv. 4, 401-404.

Nussey D.H., Wilson A.J. and Brommer J.E., 2007. The evolutionary ecology of individual phenotypic plasticity in wild populations. J. Evol. Biol. 20, 831-844.

Nyström P., 1999. Ecological impact of introduced and native crayfish on freshwater communities: European perspectives. Crustacean Issues, 11, 63-85.

Nyström P., 2002. Ecology. In: Holdich D.M. (ed.), Biology of Freshwater Crayfish, Blackwell Scientific Press, Oxford, 192-224.

Olden J., McCarthy J.M., Maxted J.T., Fetzer W.W. and Vander Zanden M.J., 2006. The rapid spread of rusty crayfish (Orconectes rusticus) with observations on native crayfish declines in Wisconsin (U.S.A.) over the past 130 years. Biol. Invasions 8, 1621-1628.

Oluoch A.O., 1990. Breeding biology of the Louisiana red swamp crayfish Procambarus clarkii Girard in Lake Naivasha, Kenya. Hydrobiologia, 208, 85-92.

Pauly D., 1980. On the interrelationships between natural mortality, growth parameters and mean environmental temperature in 175 fish stocks. J. Coun. CIEM, 39, 175-192.

Pauly D., 1981. The relationships between gill surface area and growth performance in fish: a generalization of Von Bertalanffy's theory of growth. Meeresforsch 28, 251-282.

Pauly D. and Gaschütz G., 1979. A simple method for fitting oscillating length growth data, with a program for pocket calculators. I.C.E.S. CM 1979/6:24. Demersal Fish Cttee, 26 p.

Pérez-Bote J.L., Pula H.J. and Cascos G., 2000. Distribucion del cangrejo rojo Procambarus clarkii Girard 1859 (Decapoda, Cambaridae) en Extremadura. Graellsia, 56, 71-78.

Powell D.G., 1979. Estimation of mortality and growth parameters from the length-frequency in the catch. J. Coun. CIEM, 175, 167-169

Ramalho R.O., Correia A.M. and Anastácio P.M., 2008. Effects of density on growth and survival of juvenile red swamp crayfish, Procambarus clarkii (Girard), reared under laboratory conditions. Aquacul. Res., 39, 577-586. 
Reynolds J.D., 2002. Growth and reproduction. In: Holdich D.M. (eds.), Biology of freshwater crayfish, Blackwell, Oxford, 151-181.

Rodríguez C.F., Bécares E., Fernández-Aláez M. and Fernández-Aláez C., 2005. Loss of diversity and degradation of wetlands as a result of introducing exotic crayfish. Biol. Invasions, 7, 75-85.

Sakai A.K., Allendorf F.W., Holt J.S., Lodge D.M., Molofsky J., With K.A., Baughman S., Cabin R.J., Cohen J.E., Ellstrand N.C., McCauley D.M., O’Neil P., Parker I.M., Thompson J.N. and Weller S.G., 2001. The population biology of invasive species. Ann. Rev. Ecol. Syst., 32, 305-332.

Scalici M. and Gherardi F., 2007. Structure and dynamics of an invasive population of the red swamp crayfish (Procambarus clarkii) in a Mediterranean wetland. Hydrobiologia, 583, 309-319.

Scalici M. and Gibertini G., 2002. I gamberi alloctoni nel Lazio (Italia). Atti del Convegno Nazionale "La gestione delle specie aliene in Italia. Il caso della nutria e del gambero rosso della Louisiana". Firenze, 24-25 ottobre 2002, 109-115.

Scalici M. and Gibertini G., 2007. Feeding habits of the crayfish Austropotamobius pallipes (Decapoda, Astacidae) in a brook of Latium (central Italy). Ital. J. Zool., 74, 157-168.

Scalici M. and Gibertini G. 2009. Molt and gastroliths in Austropotamobius pallipes (Lereboullet, 1858). Knowl. Managt. Aquatic Ecosyst., 394-395, 1-14.

Scalici M., Belluscio A. and Gibertini G., 2008a. Understanding the population structure and dynamics in threatened crayfish. J. Zool., 275, 160-171.

Scalici M., Macale D., Schiavone F., Gherardi F. and Gibertini G., 2008b. Effects of urban isolation on the river crab growth. Fund. Appl. Limnol., 172, 67-174.

Scalici M., Scuderi S., Gherardi F. and Gibertini G., 2008c. Growth of two river crab species of the genus Potamon (Savigny, 1816). Crustaceana 81, 119-123.

Scalici M., Chiesa S., Gherardi F., Gibertini G. and Nonnis Marzano F., 2009a. The new alien threat for the Italian continental waters from the crayfish gang: the Australian Cherax destructor Clark, 1936. Hydrobiologia, 632, 341-345.

Scalici M., Chiesa S. and Gibertini G., 2009b. Progress in understanding population structure and dynamics in inland water macrodecapods for biomonitoring programs. Atti del "IX Colloquium Crustacea Decapoda Mediterranea”, Torino (Italy), 2-6 Settembre 2008, 169-187.

Scalici M., Pitzalis M. and Gibertini G., 2009c. Crayfish distribution updating in central Italy. Knowl. Managt. Aquatic Ecosyst., 394-395, 1-6.

Scalici M., Chiesa S., Scuderi S., Celauro D. and Gibertini G., 2010. Population structure and dynamics of Procambarus clarkii (Girard, 1852) in a Mediterranean brackish wetland (Central Italy). Biol. Invasions, 12, 1415-1425.

Scuderi S., Scalici M. and Gibertini G., 2006. The freshwater crab Potamon fluviatile (Herbst, 1785) in the Monterano Natural Reserve (Rome, Italy). J. Freshw. Biol., Quaderni ETP, 34, 345-350.

Simberloff D., 2003. How much information on population biology is needed to manage introduced species? Conserv. Biol., 17, 83-92.

Slater F.M. and Rayner G., 1993. Austropotamobius pallipes in otter diet in the middle catchment of central Wales. Freshw. Crayfish, 9, 365-367.

Somers K.M. and Stechey D.P.M., 1986. Variable trappability of crayfish associated with bait type, water temperature and lunar phase. Am. Midl. Nat., 116, 36-51.

Souty-Grosset C., Holdich D.M., Noël P.Y., Reynolds J.D. and Haffner P., 2006. Atlas of Crayfish in Europe, Muséum national d'Histoire naturelle, Paris, $187 \mathrm{p}$.

Sparre P. and Venema S.C., 1996. Introduction à l'évaluation des stocks de poissons tropicaux, Document technique sur les pêches, FAO, Rome, $407 \mathrm{p}$.

Stephens P.A. and Sutherland W.J., 1999. Consequences of the Allee effect for behaviour, ecology and conservation. Trends Ecol. Evol., 14, 401-405.

Strayer D.L., 2010. Alien species in fresh waters: ecological effects, interactions with other stressors, and prospects for the future. Freshw. Biol., 55, 152-174.

Strayer D.L., Eviner V.T., Jeschke J.M. and Pace M.L., 2006. Understanding the long-term effects of species invasions. Trends Ecol. Evol., 21, 645-651.

Taketomi Y., Murata M. and Miyawaki M., 1990. Androgenic gland and secondary sexual characters in the crayfish Procambarus clarkii. J. Crustacean Biol., 10, 492-497. 
Takimoto G., 2009. Early warning signals of demographic regime shifts in invading populations. Popul. Ecol., 51, 419-426.

Turchin P., 1999. Population regulation: a synthetic view. Oikos, 84, 153-159.

Usio N. and Townsend C.R., 2004. Roles of crayfish: consequences of predation and bioturbation for stream invertebrates. Ecology, 85, 807-822.

Von Bertalanffy L., 1938. A quantitative theory of organic growth. Human Biol., 10, 181-243.

Wetherall J.A., 1986. A new method for estimating growth and mortality parameters from lengthfrequency data. ICLARM Fishbyte, 4, 12-14.

White E.P., Ernest S.K.M., Kerkhoff A.J. and Enquist B.J., 2007. Relationships between body size and abundance in ecology. Trends Ecol. Evol., 22, 323-330.

Whitledge G.W. and Rabeni C.F., 1997. Energy sources and ecological role of crayfishes in an Ozark stream: insights from stable isotopes and gut analysis. Can. J. Fish. Aquat. Sci., 54, 2555-2563.

Wilson K.A., Magnuson J.J., Lodge D.M., Hill A.M., Kratz T.K., Perry W.L. and Willis T.V., 2004. A longterm rusty crayfish (Orconectes rusticus) invasion: dispersal patterns and community change in a north temperate lake. Can. J. Fish. Aquat. Sci., 61, 2255-2266. 